\title{
Estimation of Race and Sex Using Ischiopubic Index and Subpubic Angle in Upper Egypt
}

\author{
Samira M. Saleh ${ }^{1}$
}

${ }^{1}$ Forensic Medicine and Clinical Toxicology Department, Qena Faculty of Medicine, South Valley University, Qena, Egypt

\begin{abstract}
Accurate estimations of race and sex are essential tools in forensic anthropology. The pelvic bones are the most accurate bones from which sex can be determined, where ischiopubic index and subpubic angle are important parameters in these bones. The objective of our study is to determine ischiopubic index and subpubic angle in Egyptian males and females and compare them with other populations. Antero posterior radiographs of 120 adult males and females (aged from 18 to 70 years) were studied for measurement of the pubic length, the ischial length and subpubic angle. Results: the mean of pubic length, ischial length, ischiopubic index and subpubic angle in Egyptians males were $72.4 \mathrm{~mm}, 80.6$ $\mathrm{mm}, 86.3$ and $102.4^{\circ}$ respectively. The mean of pubic length, ischial length, ischiopubic index and subpubic angle in Egyptians females were $83.5 \mathrm{~mm}, 74.5 \mathrm{~mm}, 103.5$ and $141.2^{\circ}$ respectively. The mean of pubic length was significantly increased in females than males in the $(\mathrm{p}<0.05)$, while the mean ischial length was significantly higher in males than females $(p<0.05)$, the mean ischiopubic index was significantly higher in females than males $(\mathrm{p}<0.05)$, while the mean of subpubic angle in females was significantly higher than males
\end{abstract}

\section{Introduction and objective}

$\mathrm{O}$ ur study was done to record the ischiopubic index and subpubic angle of adult Egyptian males \& females, then the over all mean was determined and compared to other populations for sexual and racial estimation.

Skeletal characteristics vary among populations, so each population should have specific standards to optimize the accuracy of identification (Iscan, 2005)

The pelvic bones are the most accurate bone from which sex is determined, about $95 \%$ of sexing accuracy can be expected if the pelvis is complete (Krogman and Iscan 1986).

The ischiopubic index is the measurement of the distance between the acetabulum and the pubic tubercle of the pelvic bone (pubic length) divided by the distance between the acetabulum and ischial tuberosity of the pelvic bone (ischial length) multiplied by hundred (Rogers and Saunders, 1994).

The sub-pubic angle is one of the most important angles of the pelvic outlet which present below the symphysis pubis as a triangular interval between the inferior rami of the pubic bones. It is also referred to as the pubic arch (Keith and Dalley, 1999).

Gender differentiation in skeletal human remains is an important component of anthropological investigations and should be based on measurements and clarifications on the entire skeleton to be significant. Singh and Potturi (1978) reported that it is almost impossible to determine the sex of an individual from the skeletal remains unless all the bones are available, except in case of the hip bones.

The skeletal remains of infants and children have been excluded from investigations of sex determination as researchers believed that sex determination does not occur until reaching puberty (Rupich 1996), and the indices of sexual dimorphism in the ischiopubic complex do not begin until puberty (Bruzek, 2002).

\section{Materials and methods}

The study was done on 120 anteroposterior pelvic radiographs (60 males and 60 females) in Qena university hospital. The age of the patients ranged from 18- 70 years, the radiographs were chosen with normal pelvic bones, no fractures and good alignment at the inferior margins of the pubic bones at the pubic symphysis. Measurement of pubic length was done from the center of the tri-radiate acetabulum to the pubic tubercle, ischial length from acetabulum to the maximum ischial tuberosity. Measurement of subpubic angle by a protractor where two tangential lines were drawn at the inferior borders of the pubic rami and intersecting at subpubic angle

The results were analyzed with SPSS version 11 . Two-sample $t$ tests were used to compare each pair of studies for males and for females separately. 


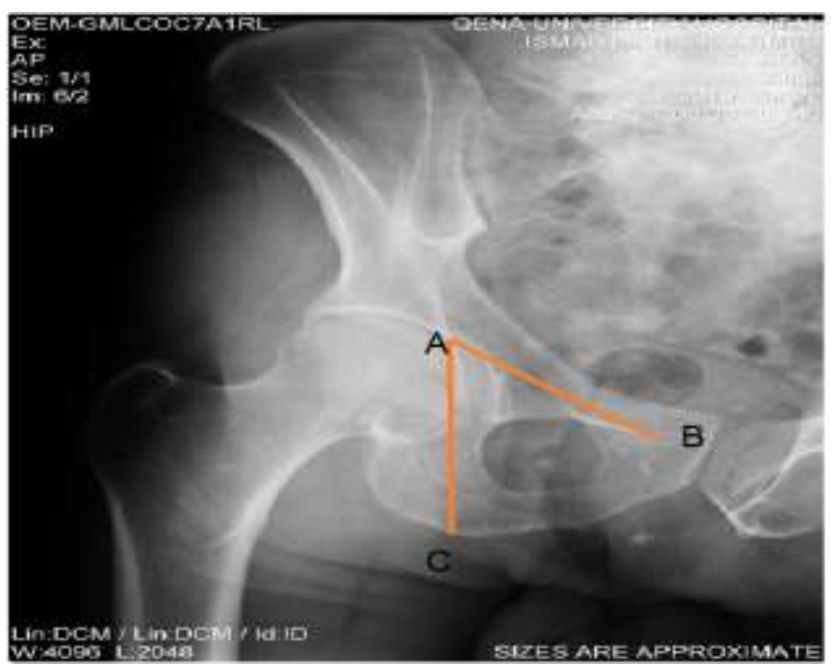

Figure (1): Anteroposterior radiograph of pelvis illustrates measurement ofpubic length (AB) and ischeal length (AC).

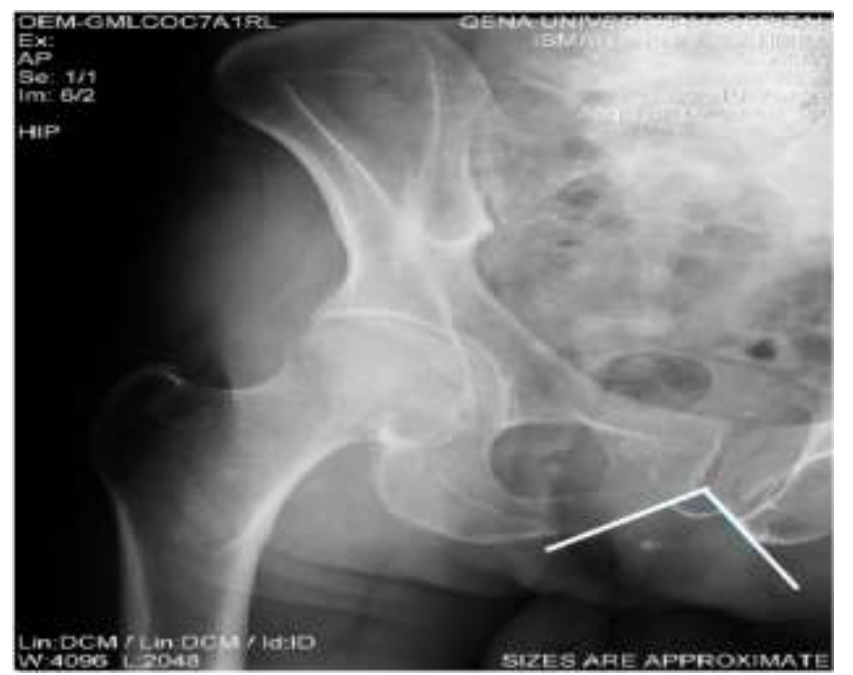

Figure (2): Anteroposterior radiograph of pelvis illustrates measurement of the subpubic angle.

\section{Results}

Table 1 represents the range, mean and standard deviation (S.D) of the four measurements (pubic length, ischial length, ischiopubic index and subpubic angle) for male and female subjects in upper Egypt. The mean \pm S.D values of pubic length in males and females were $72.4 \pm 8.8 \mathrm{~mm}$, and $83.5 \pm 8.5 \mathrm{~mm}$ respectively, while the mean \pm S.D values of ischial length in males and females were $80.6 \pm 6.9 \mathrm{~mm}$ and $74.5 \pm 7.8 \mathrm{~mm}$ respectively. The ischiopubic index mean \pm S.D value in males was $86.3 \pm 9.4$, and in females was $103.5 \pm 7.9$, the number of males identified by sex represents $65.4 \%$, while the number of females identified by sex represents $67.8 \%$
The subpubic angle mean \pm S.D values in males and females were $99.4^{\circ} \pm 10.6^{\circ}$ and $141.2^{\circ} \pm$ $12.5^{\circ}$ respectively. the number of males identified by sex represents $71.3 \%$, while the number of females identified by sex represents $66.2 \%$

Table 2 represents the mean \pm S.D values of ischiopubic index of previously studied populations compared to the present study where all populations show sexual dimorphism

Table 3 shows the mean \pm S.D values of subpubic angle of previously studied populations (Ugandans, Malawians, Indians, Amerindians Libben and white and black Americans) compared to results of our study 
Table (1): Comparison between male and female Egyptian pubic length, ischial length, ischio-pubic index and subpubic angle

\begin{tabular}{|l|l|l|l|}
\hline Parameters & Males (60) & Females (60) & P value \\
\hline $\begin{array}{c}\text { Pubic length } \\
\text { Range } \\
\text { Mean } \pm \text { S.D }\end{array}$ & $60-81 \mathrm{~mm}$ & $66-87 \mathrm{~mm}$ & \multirow{2}{*}{$<0.05$} \\
\cline { 2 - 3 } & $72.4 \pm 8.8 \mathrm{~mm}$ & $83.5 \pm 8.5 \mathrm{~mm}$ & \\
\hline $\begin{array}{l}\text { Ischial length } \\
\text { Range } \\
\text { Mean } \pm \text { S.D }\end{array}$ & $75-89 \mathrm{~mm}$ & $64-83 \mathrm{~mm}$ & \multirow{2}{*}{$<0.05$} \\
\cline { 2 - 3 } $\begin{array}{c}\text { Ischio-pubic index } \\
\text { Range } \\
\text { Mean } \pm \text { S.D } \\
\text { Identified by sex }\end{array}$ & $79-93.6 .9 \mathrm{~mm}$ & $74.5 \pm 7.8 \mathrm{~mm}$ & \\
\cline { 2 - 3 } & $86.3 \pm 9.4$ & $98-110$ & \multirow{2}{*}{$<0.05$} \\
\hline $\begin{array}{c}\text { Subpubic angle } \\
\text { Range }\end{array}$ & $86^{\circ}-127^{\circ}$ & $67.8 \% 7.9$ & \\
$\begin{array}{c}\text { Mean } \pm \text { S.D } \\
\text { Identified by sex }\end{array}$ & $99.4^{\circ} \pm 10.6^{\circ}$ & $141.2^{\circ} \pm 12.5^{\circ}$ & \multirow{2}{*}{$<0.01$} \\
\cline { 2 - 3 } & $71.3 \%$ & $66.2 \%$ & \\
\hline
\end{tabular}

$P>0.05=$ non-significant difference; $P<0.05=$ significant difference

Table (2): Comparison between Ischio-pubic index in different population groups and male and female Egyptian in the present study

\begin{tabular}{|l|l|l|l|l|}
\hline Populations & $\begin{array}{l}\text { Males } \\
\text { Mean } \pm \text { S.D }\end{array}$ & $\begin{array}{l}\text { Females } \\
\text { Mean } \pm \text { S.D }\end{array}$ & P value & Authors \\
\hline Kalabari people of Nigeria & $87.3 \pm 6.1$ & $104.1 \pm 4.2$ & $<0.05$ & Oladipo et al 2012 \\
\hline Ikwerre people of Nigeria & $81.1 \pm 7.5$ & $101.1 \pm 3.7$ & $<0.05$ & Oladipo et al 2012 \\
\hline Black Malawians & $85.0+15.7$ & $104.6+15.7$ & $<0.05$ & Igbigbi \& Msamati; 2000 \\
\hline White American & $63.7+7.8$ & $88.4+8.5$ & $<0.05$ & Tague 1989 \\
\hline Black Americans & $65.8+8.7$ & $85.2+8.5$ & $<0.05$ & Tague 1989 \\
\hline Portuguese & $78.2+6.2$ & $71.3+3.1$ & $<0.05$ & Phenice, 1989 \\
\hline $\begin{array}{l}\text { South-South } \\
\text { Nigerians }\end{array}$ & $81.4+6.4$ & $104.2+11.1$ & $<0.05$ & Oladipo et al 2009 \\
\hline France & $82.0+7.2$ & $94.5+3.1$ & $<0.05$ & Wasbum, 1948 \\
\hline
\end{tabular}

$P>0.05=$ non-significant difference $; P<0.05=$ significant difference

Table (3): Comparison between subpubic angle in different population groups and male and female Egyptian in the present study

\begin{tabular}{|l|l|l|l|l|l|}
\hline Population & $\begin{array}{l}\text { Males } \\
\text { Mean } \pm \text { S.D }\end{array}$ & $\begin{array}{l}\text { Females } \\
\text { Mean } \pm \text { S.D }\end{array}$ & P value & Authors & $\begin{array}{l}\text { Over all } \\
\text { mean angles }\end{array}$ \\
\hline Indians & $73.8^{\circ} \pm 8.2$ & $98.2^{\circ} \pm 8.4$ & $<0.001$ & Tague 1989 & $80.3^{\circ}$ \\
\hline Malawians & $99.2^{\circ} \pm 15.7$ & $129.1^{\circ} \pm 14.6$ & $<0.001$ & Msamati et al., 2005 & $114.2^{\circ}$ \\
\hline Ugandans & $93.86^{\circ} \pm 21.12$ & $116.11^{\circ} \pm 17.79$ & $<0.001$ & Igbigbi and Igbigbi, 2003 & $98.2^{\circ}$ \\
\hline White Americans & $63.7^{\circ} \pm 7.8$ & $88.4^{\circ} \pm 8.5$ & $<0.001$ & Igbigbi and Igbigbi, 2003 & $76.1^{\circ}$ \\
\hline Black Americans & $65.8^{\circ} \pm 8.7$ & $85.2^{\circ} \pm 10.4$ & $<0.001$ & Igbigbi and Igbigbi, 2003 & $75.5^{\circ}$ \\
\hline Libbens & $68.8^{\circ} \pm 7.8$ & $95.2^{\circ} \pm 10.8$ & $<0.001$ & Tague 1989 & $80.3^{\circ}$ \\
\hline Amerindians & $67.4^{\circ} \pm 8.1$ & $93.1^{\circ} \pm 10.4$ & $<0.001$ & Igbigbi and Igbigbi, 2003 & $80.3^{\circ}$ \\
\hline Egyptian (previous study & $102.3^{\circ} \pm 12.5$ & $143.3^{\circ} \pm 15.8$ & $<0.001$ & Abd-El-hameed et al, 2009 & $122.8^{\circ}$ \\
\hline Egyptian (present study & $99.4^{\circ} \pm 10.6$ & $141.2^{\circ} \pm 12.5$ & $<0.001$ & ------- & $120.3^{\circ}$ \\
\hline
\end{tabular}

$P>0.05=$ non-significant difference $; P<0.05=$ significant difference $; P<0.001=$ highly significant

\section{Discussion}

This study has established the presence of sexual dimorphism in ischiopubic index in Egyptians. More females were accurately identified by sex than males $(67.8 \%, 65.4 \%)$ respectively, while regarding the subpubic angle more males were accurately identified by sex than females $(71.3 \%, 66.2 \%)$

This result agreed with previous reports in Nigerians (Oladipo et al 2012), Malawians (Igbigbi \&
Msamati; 2000), France (Wasbum, 1968) Portuguese (Phenice, 1989), Amerindians (Tague, 1989), White and Black Americans (Tague, 1989)

Ekanem et al. (2009) conducted a study on the radiographic determination of sex differences in ischio-pubic index of a Nigerian population, and their results revealed that the sex differences of the pubic length, ischial length and ischio-pubic index was found 
to be significant. The ischio-pubic index of the females was discovered to be higher than that of males

In this study comparison of the subpubic angles of Egyptians with other populatio0ns showed that there was a highly significant racial variability, Egyptians had an overall mean of subpubic angle equal to $120.3^{\circ}$ which is higher than that in Malawians (Msamati et al., 2005), Indians and Libbens (Tague 1989), Ugandans, Amerindians, White and black Americans (Igbigbi and Igbigbi, 2003). A previous study by Abd-El-hameed et al. (2009) was done in Assiut University hospital reported that the overall mean of subpubic angle in Egyptians is $122.8^{\circ}$ which was a bit higher than the present study.

Though the primary function of the pelvis in males and females is for loco-motion, it is specially adapted for childbirth in females (Ekanem et al., 2009) - This may explain the significantly higher sexual differences in ischiopubic index and subpubic angle observed in females in all races when compared with that of males

The presence of racial and sexual, variability of the sub-pubic angle could be explained by presence of genetic, dietary and environmental factors

\section{Conclusion}

The present study has demonstrated the presence of sexual dimorphism in the ischio-pubic index and subpubic angle in Egyptians, and they are of great importance in relation to other populations. We advice that further studies should be done to compare the ischiopubic index and subpubic angle in other Egyptian governorates.

\section{References}

Abd-El-hameed, S.Y., Mohamed, A.A. and Thabet, H. Z. (2009): Determination of subpubic angle in Egyptian population. Mansoura J. Forensic Med. Clin. Toxicol. 17 (1): 41- 53

Bruzek J. (2002): A method for visual determination of sex, using the human hip bone. Am. J. of Phys. Anthropol., 117: 157-168.

Ekanem, T.A. Udongwu and S. Singh, (2009): Radiographic determination of sex differences in ischiopubic index of a Nigerian population. Int. J. Biol. Anthropol., 3: 2.

Igbigbi P.S. and Msamati B.C. (2000): Ischiopubic index in adult black Malawians. East Afr. Med. J. 77:514-516.

Igbigbi, P. S. and Igbigbi, A. M., (2003): Determination of sex and race from the subpubic angle in Ugandan subjects. Am. J Forensic Med. Pathol., 24: $168-172$

Iscan, M. Y. (2005): Forensic anthropology of sex and body size. Forensic Sci. Int., 147: 107-112

Keith, M. and A. Dalley, 1999. Clinically Oriented Anatomy. 4th Edn., Lippincott Williams and Wilkins: pp: 332-331, 506.

Krogman, W. M. and Iscan, M. Y. (1986): The Human Skeleton in Forensic Medicine. 2nd edition, Ch. 6, Charles C. Thomas. Springfield, IL, P.P. 208224.

Msamati, B. C.; Igbigbi, P. S. and Manda, J. K. (2005) : "The subpubic angle in adult indigenous Malawian subjects". East Afr. Med. J., 82(12): 643-648

Oladipo G.S., Okoh P.D, and Leko B., (2012): Radiologic studies of pubic length, ischial length and ischiopubic index of adult Kalabaris and Ikwerres of Nigeria. Res. J. Med. Med. Sci., 3(2): 99-102.

Oladipo G.S, Ugboma HAA, Suleiman YA, (2009a): Comparative study of sub-pubic angles in adult Ijaws and Igbo's. Asia J. med. Sci. 1 (2): 26-29.

Phenice T.W. (1989): A newly developed visual method of sexing the OS pubis. Am. J. Phys. Anthrop. 30:297-301

Rogers, T. and S. Saunders, (1994): Accuracy of sex determination using morphological traits of the human pelvis. J Forensic Sci., 39: 1047-1056.

Rupich R.C. 1996. Gender and Race differences in bone mass during Infancy. J Hum Biol 12: 56- 58

Singh S. and Potturi B.R. 1978. Greater sciatic notch in sex determination. Journal of Anatomy 125(3):619-624.

Tague, R. G. (1989): Variation in pelvic size between male and females. Am. J. Phys. Anthropol., 80:59-71

Washburn, S.L., (1968): Sex differences in pubic bone. Am. J. Phys. Anthropol., 6: 199-207. 


\section{الملخص العربي}

تقدير العرق والجنس باستخدام مؤشر طول عظم القخذ المى طول عظم العانة والزاوية السفلى لعظم العانة في مصر العليا

\section{سميرة محمد صالح'}

المقدمة : يعتبر التقدير الدقيق للعرق والجنس من الأدوات الهامة في الطب الشرعي والبدني. ولقد أثنتت العديد من التحقيقات

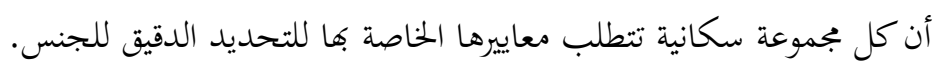
وتعتبر عظام الحوض هى الاكثر دقة من حيث استخدامها في تحديد الجنس، حيث مؤشر طول عظم الفخذ الى طول عظم

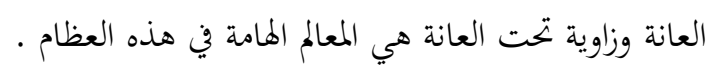

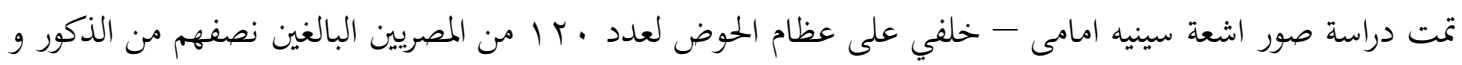

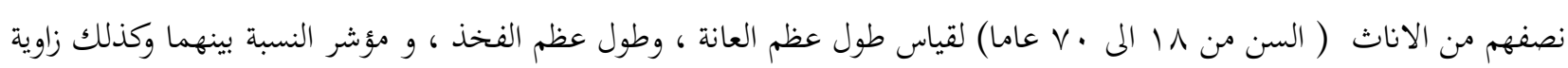
تحت العانة و تم عمل دراسات الحصائية.

النتائج : ظهر من الدراسة ان متوسط قيم طول عظم العانة ، وطول عظم الفخذ، و مؤشر النسبة بينهما وزاوية تحت العانة في

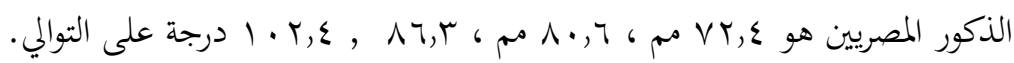

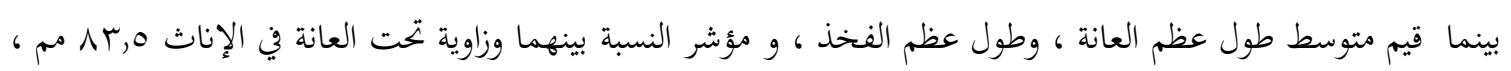

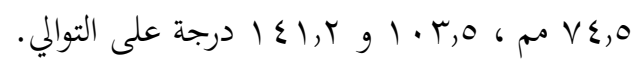
و كان متوسط طول عظم العانة في الإناث اطول منه في الذكور و له دلالة احصائية، وكان متوسط طول عظم الفخذ في

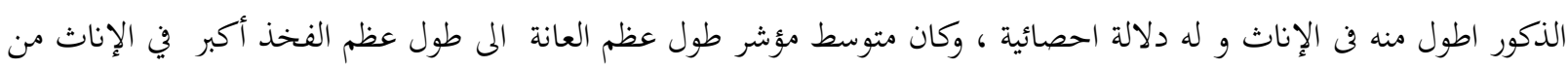
الذكور و له دلالة احصائية.

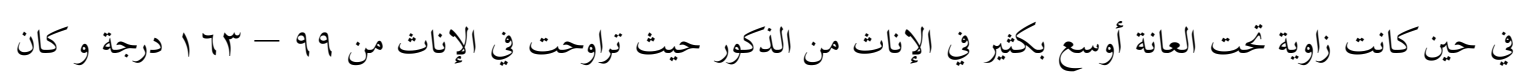

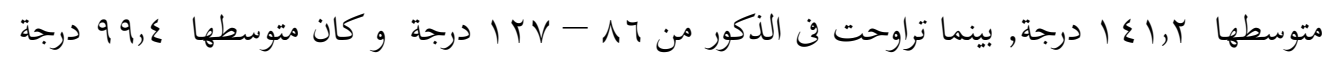
ا قسم الطب الشرعي والسموم الإكلينيكية - كلية طب قنا - جامعة جنوب الوادي 